\title{
Time Travel
}

André Simon

Korrespondenz:

Dr. med. André Simon

Dörflistrasse 14

CH-8057 Zürich

andre.simon@hin.ch
Once upon a time in the realm towards the sunrise and far away, there lived a fisherman YISHI-YI. The town, where he lived, was small and has finally fallen asleep. The towns people, still practised ancient customs dating back many centuries, and they still wore traditional clothing. Their way of life was simple, and it was common place to see little old women washing their vegetables in the town well. Others were hard at work on their farms. The fisherman YISHI-YI was known for his special method of fishing, which was without a line and hook, but with a straight metal rod on which the fish would jump onto. After stroking the fish, he freed them back into the river. This remarkable way of fishing became well known, and the fame of the famous fisherman reached the ears of the Emperor himself.

One day YISHI-YI was fishing with his straight rod. The river was flowing gently, the birds were singing sweetly, and the fish jumped voluntarily onto the straight metal rod. Suddenly, a horse drawn gold gilded carriage appeared. The coachman opened the door bowed with veneration, and the Emperor himself stepped down from the carriage. The Emperor realized that the old man possessed mystic powers and invited him to explain his astonishing method of fishing. YISHI-YI told the Emperor that the magic rod is a piece of an old counting frame (abacus). With this rod, he was able to calculate the exact day and hour to visualize a rainbow. Thereby, the rod allowed him to follow the rainbow and to travel vast distances. However, when he returned from those travels, what he thought had been a day's journey, had in fact taken many years. Afterwards, YISHIYI石头 promised the Emperor to visit his descendants on his return from his long journey. The Emperor thanked him and returned to his palace.

Many thousand years have elapsed since the odd fisherman described a strange happening, the travel that seemed a single day's journey, but which in fact lasted many years. Had the odd fisherman delivered his promise and visited the Emperor's descendants after his long travels?

The answers came at the end of 19th century. During this period in the University-town of Zurich, there lived a poor student called Albert. Connected between downtown Zurich and the University was a track for a wheeled vehicle. This connection formed

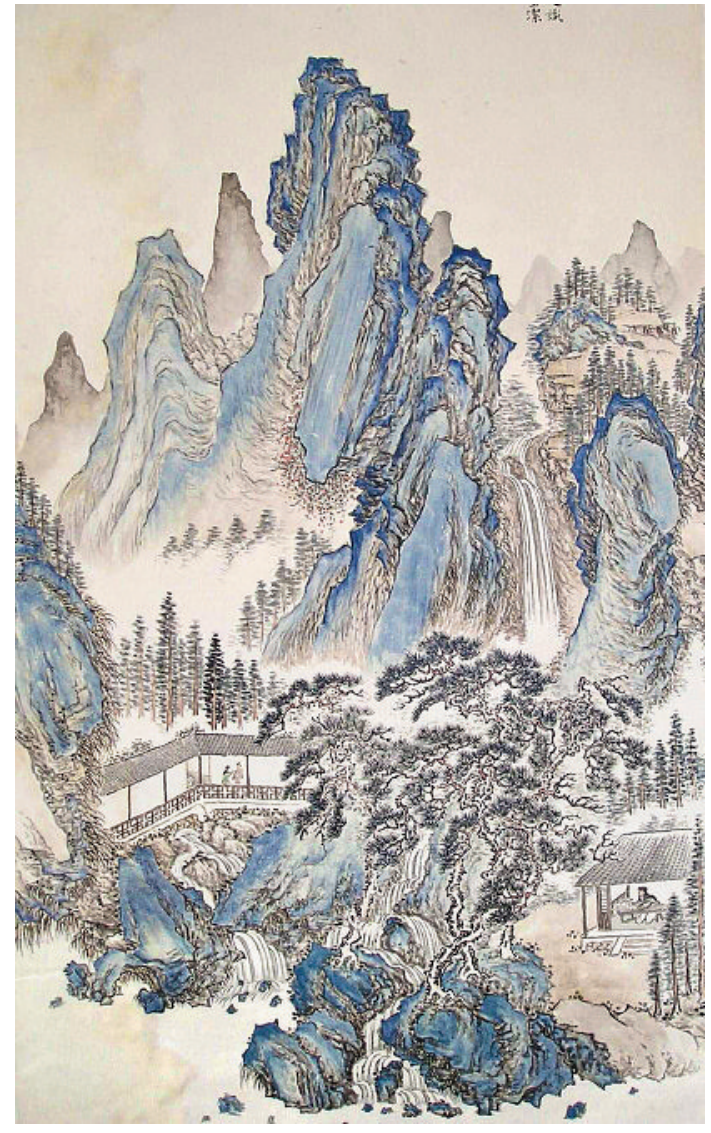

a straight rod. The students jumped voluntarily onto this vehicle, as the fish jumped onto the fisherman's magic rod. The time: taken up to the University was three minutes, to downtown, two minutes. This time difference, for such a same short distance, was for Albert peculiar. He postulated that if we keep accelerate our speeds while others stand still, our clock will go slower than the clock of others. This so called «time dilation» is part of his Theory of Relativity. Albert today known as Professor Albert Einstein was from birth on closely linked to the mathematics. Born on March 14th which written numerically as 3.14 is the number $\pi$. Number $\pi$ is one of the most important mathematical constants.

In the Year 2011 Time dilatation applies to satellites that orbit the Earth, as they move forward in time. The satellites and advanced technology are part of the World Wide Web, we know today. Advanced technology is indistinguishable from magic! 